\title{
Transient up- and down-regulation of expression of myosin light chain 2 and myostatin mRNA mark the changes from stratified hyperplasia to muscle fiber hypertrophy in larvae of gilthead sea bream (Sparus aurata L.)
}

\author{
Stella Georgiou ${ }^{1} \cdot$ Hélène Alami-Durante ${ }^{2}$ Deborah M. Power ${ }^{3}$. \\ Elena Sarropoulou ${ }^{4} \cdot$ Zissis Mamuris $^{1} \cdot$ Katerina A. Moutou $^{1}$
}

Received: 13 March 2015 / Accepted: 6 July 2015 / Published online: 6 August 2015

(C) Springer-Verlag Berlin Heidelberg 2015

\begin{abstract}
Hyperplasia and hypertrophy are the two mechanisms by which muscle develops and grows. We study these two mechanisms, during the early development of white muscle in Sparus aurata, by means of histology and the expression of structural and regulatory genes. A clear stage of stratified hyperplasia was identified early in the development of gilthead sea bream but ceased by $35 \mathrm{dph}$ when hypertrophy took over. Mosaic recruitment of new white fibers began as soon as $60 \mathrm{dph}$. The genes $m l c 2 a$ and $m l c 2 b$ were expressed at various levels during the main phases of hyperplasia and hypertrophy. The genes myog and $m l c 2 a$ were significantly upregulated during the intensive stratified formation of new fibers and their expression was significantly correlated. Expression of $m s t n 1$ and igfl increased at $35 \mathrm{dph}$, appeared to regulate the hyperplasia-to-hypertrophy transition, and may have stimulated the expression of $m l c 2 a, m l c 2 b$ and collal at the onset of mosaic hyperplasia. The up-regulation of $m s t n 1$
\end{abstract}

This research was co-financed by Greek National Funds through the Operational Program "Education and Lifelong Learning" of the National Strategic Reference Framework (NSRF) - Research Funding Program: Heracleitus II, Investing in Knowledge Society through the European Social Fund and COST Action FA0801 "LarvaNet".

Katerina A. Moutou

kmoutou@bio.uth.gr

1 Department of Biochemistry \& Biotechnology, University of Thessaly, Ploutonos 26, Larissa, Greece

2 UR 1067 Nutrition Métabolisme Aquaculture, INRA, Aquapôle, F-64310 Saint-Pée-sur-Nivelle, France

3 Centre of Marine Sciences (CCMar), Universidade do Algarve, Faro, Portugal

4 Institute of Marine Biology \& Genetics, Hellenic Centre for Marine Research, Heraklion, Crete, Greece at transitional phases in muscle development indicates a dual regulatory role of myostatin in fish larval muscle growth.

Keywords Gene markers · mlc2 · Muscle cellularity · Myogenic factors $\cdot$ Gilthead sea bream

\section{Introduction}

Muscle develops and grows through two fundamental processes: the recruitment of new fibers (hyperplasia) and the increase in size of existing fibers (hypertrophy). The two processes are differentially regulated throughout the lifecycle in teleosts: hyperplastic muscle growth dominates during the initial stages of development, whereas hypertrophy takes over later on. In teleosts that reach a large adult body size such as the gilthead sea bream (Sparus aurata L.), fiber recruitment occurs in three distinct phases during ontogeny: embryonic myogenesis that gives rise to two morphologically and functionally distinct muscle types forming the primary myotome; stratified hyperplasia, during which dorsal and ventral germinal zones add new white muscle fibers in discrete layers apically; and mosaic hyperplasia in which deep myogenic progenitor cells (MPCs) are recruited to fuse and form new myotubes or to contribute to the expansion in size of existing muscle fibers post-metamorphosis. The result is the generation of muscle fibers of variable diameter creating the mosaic appearance of the mature teleost musculature (Rowlerson et al. 1995). The axial musculature or fillet can account for up to $70 \%$ of the fish body mass (Bone 1978) and is made up of serial myotomes of muscle fibers, mainly fast white fibers.

White muscle cellularity (number and size of muscle fibers) is a highly plastic process that depends both on intrinsic factors such as species and strain (e.g., Weatherley et al. 1988; 
Valente et al. 1999) and extrinsic factors that include temperature and exercise (for a review, see Johnston 2006), plane of nutrition (e.g., Weatherley et al. 1979; Kiessling et al. 1991; Salze et al. 2014) and dietary nutrient composition (e.g., Fauconneau et al. 1997; Alami-Durante et al. 1997, 2010a, 2010b, 2011, 2014; Johnston et al. 2002; Silva et al. 2009); it also follows seasonal cycle patterns (Alami-Durante et al. 2007) and is strongly linked to the stage of development (for a review, see Johnston 1999). Most importantly, muscle cellularity is strongly correlated with the final size that a fish may attain. For example, Weatherley and colleagues (1988) compared ten different fish species and found that growth capacity largely depended on the maintenance of white muscle fiber recruitment and the number of small-diameter fibers. Similarly, significant differences in the final size of four isolated morphs of Arctic charr (Salvelinus alpinus) were strongly correlated with the number of white muscle fibers (Johnston et al. 2004). Furthermore, genetically modified Arctic charr carrying an extra growth hormone gene had significantly higher numbers of white muscle fibers compared with nongenetically modified fish of either the same age or the same size (Pitkänen et al. 2001).

The generation and enlargement of muscle fibers requires the synthesis and deposition of sarcomeric proteins that make up the bulk of differentiated muscle cells. Myosin is a major sarcomeric protein and consists of two heavy chains (MHCs) and four light chains (MLCs) combined in a long coiled $\alpha$ helical tail and two heads. MHCs and MLCs exist in multiple isoforms that can exhibit both tissue-specific and stagespecific patterns of expression (Whalen et al. 1981; Gauthier et al. 1982) and are regulated by hormonal status and environmental cues (Gerlach et al. 1990; Hirayama et al. 1998; Moutou et al. 2001). Fish myosin expression is also known to be regulated by ration level (Overturf and Hardy 2001), fasting followed by satiation feeding (Bower et al. 2009) and some macro- and micro-nutrients (Hevroy et al. 2006; Alami-Durante et al. 2010b, 2011, 2014; Campos et al. 2010; Betancor et al. 2013).

In gilthead sea bream, two isoforms of myosin light chain $2 a(m l c 2 a)$, which encode a 170-amino-acid (aa) peptide, have been isolated and characterized from white muscle (Moutou et al. 2001; Sarropoulou et al. 2006). Three alternative transcripts of $m l c 2 a$ have been isolated that are products of alternative polyadenylation site selection and encode for the same peptide but differ in the length of their 3' untranslated regions (284 bp, mlc2a-S; 788 bp, mlc2a-M; 876 bp, mlc $2 a-\mathrm{L}$; Sarropoulou et al. 2006). Preliminary work has shown that the two $m l c 2$ isoforms exhibit different expression patterns during development and in primary muscle cell cultures. Transcripts of $m l c 2 a$ are detectable at the onset of somitogenesis, increase gradually up to metamorphosis and are downregulated post-metamorphosis (Moutou et al. 2009). Expression of $m l c 2 b$ starts before hatch and remains at very low levels up until metamorphosis. Similarly, in primary muscle cell cultures, $m l c 2 a$ is the predominant isoform expressed and peaks at differentiation, whereas $m l c 2 b$ is expressed at significantly lower levels in all differentiation states (Moutou et al. 2009). In juvenile fish, the expression pattern of $m l c 2 a$ and $m l c 2 b$ is reversed, with $m l c 2 b$ expression being about 10 -fold higher than that of $m l c 2 a$ and they respond differently to growth hormone administration (Moutou et al. 2009).

The improvement of muscle mass is a major goal in aquaculture research. The identification of the molecular mechanisms underlying muscle growth will provide molecular markers that can be used during genetic or environmental selection; such markers are an important tool for the efficient management of growth. In this context, we investigated the way that the expression of the two different $m l c 2$ isoforms, namely $m l c 2 a$ and $m l c 2 b$, correlates with hyperplastic and hypertrophic growth and with other structural, regulatory and myogenic genes during the early stages of muscle development by using gilthead seabream larvae as the model.

\section{Materials and methods}

\section{Fish and sampling stages}

Gilthead sea bream (Sparus aurata L.) larvae were obtained from a commercial hatchery at Maliakos Gulf, Greece. Larvae were held in filtered, continuously aerated sea-water (salinity $29 \mathrm{ppt}$ ). Larvae were fed in excess twice a day with rotifers up to 23 days post hatch (dph) and newly hatched Artemia nauplii were co-fed from 13-25 dph during the nursing period. Rotifers were enriched by 24-h incubation in DHA Master (Inve, Belgium) and Artemia metanauplii were enriched by 24-h incubation in S.presso (Inve). Dry commercial diet was introduced on $20 \mathrm{dph}$ (INVE O.range start, wean). The microalgae Chlorella minutissima was added during the period of feeding with rotifers. Larvae were kept under a 24-h light regime up to $25 \mathrm{dph}$ and switched to 15:9 light:dark afterwards. The oxygen concentration in the seawater was 7 $\pm 2 \mathrm{mg} \mathrm{l}^{-1}$ and water temperature during the embryonic, yolksac (0-4 dph) and larval-juvenile (5-60dph) stages was 19.0土 $0.1^{\circ} \mathrm{C}\left(18.0-20.5^{\circ} \mathrm{C}\right)$.

Gilthead sea bream larvae were sampled on 5, 15, 25, 35, 45 and $60 \mathrm{dph}$. Larvae were anesthetized in 2phenoxyethanol (1:5000, Sigma-Aldrich, P1126) and the total length of 10 larvae per sampling age was measured individually with a semi-automatic image analyzer (ImageJ software, Abramoff et al. 2004). Larvae for morphometric analyses were dipped in Serra fixation buffer (ethanol 6 vol, formalin 3 vol, acetic acid $1 \mathrm{vol}$ ) and then dehydrated up to butanol (Alami-Durante 1990) in which they were kept until histological analyses. Samples for gene expression analyses were 
placed in RNAlater Reagent (Sigma-Aldrich, R0901) and held at $-20{ }^{\circ} \mathrm{C}$ until use.

\section{Quantitative histology}

A histological protocol was adapted from protocols drawn for larvae of other fish species (Alami-Durante 1990; AlamiDurante et al. 2006). Muscle morphometric analysis was performed by using 10 fish from the 5-, 15-, 25-, 35-, 45- and 60dph age groups. Gilthead sea bream larvae of 5, 15 and 25 dph were pre-embedded in agar and then dehydrated by immersion in an ethanol series (for $5 \mathrm{~min}$ in each solution) of increasing concentration $(0,25 \%, 50 \%, 75 \%$ and $100 \%)$ with a final step in butanol in which samples were held until being embedded in paraffin. Inclusion of larvae in paraffin was carried out by incubation for a total of $1 \mathrm{~h}(5-, 15-$ and 25-dph larvae) or $2 \mathrm{~h}$ (trunco-caudal region of 35-, 45- and 60 -dph larvae) in four changes of molten paraffin $\left(58^{\circ} \mathrm{C}\right)$. Serial transverse sections $(10 \mu \mathrm{m})$ were prepared by using a microtome (Leica, R2125), placed on glass slides and dried at $37^{\circ} \mathrm{C}$ for $48 \mathrm{hr}$.

Sections were stained with Ehrlich hematoxylin and $1 \%$ eosin (Alami-Durante et al. 2007) after the dewaxing of the sections in toluene (two changes for $5 \mathrm{~min}$ ), rehydration through a graded ethanol series $(100 \%, 75 \%, 50 \%$ and $25 \%$ ) and washes in distilled water. Stained sections of 10 individuals per age group were observed by using a light microscope (Leica, DM2000) coupled to a digital camera and captured images were analyzed by using ImageJ software (Abramoff et al. 2004). Cellular analyses were performed in one dorsal epaxial quadrant of myotome located in the vent region of each specimen analyzed. This quadrant of white muscle consisted of newly formed muscle fibers and older fibers and was selected for cellularity measurements, i.e., muscle hypertrophy and hyperplasia. The outline of all individual white muscle fibers was drawn and the white fiber diameter (WFD; diameter of a circle with an area equal to the muscle fiber; hereafter referred to as "fiber diameter"), area (WFA) and perimeter (WFP) were determined. The total number of white fibers (TNF) present in the dorsal quadrant of white muscle was determined for each fish, as was the total crosssectional area (TCSA) of this quadrant. Sections of 5-dph larvae were of insufficient quality for cellularity measurements and were excluded from the morphometric analysis.

\section{RNA extraction}

Total RNA was extracted from individual whole 5-, 15-, 25-, 35-, 45- and 60-dph larvae by using TRI Reagent (Sigma, T9424) according to the manufacturer's instructions. Total RNA was subsequently subjected to DNAse treatment with DNA-free (Ambion, AM1906) to remove traces of contaminating genomic DNA and was stored at $-80{ }^{\circ} \mathrm{C}$ until further use. cDNA synthesis was performed simultaneously for all samples to ensure the same reaction efficiency. cDNA was generated from $1 \mu \mathrm{g}$ total RNA by using $200 \mathrm{U} / \mu \mathrm{l}$ SuperScript II reverse transcriptase (Invitrogen, 18064-014), $3 \mu \mathrm{g}$ random primers (Invitrogen, 48190-011) and $40 \mathrm{U} / \mu \mathrm{l}$ recombinant RNaseOUT ribonuclease inhibitor (Invitrogen, 10777-019) in a total reaction volume of $27 \mu \mathrm{l}$.

\section{Relative quantification of gene expression by real-time quantitative polymerase chain reaction analysis}

The gene expression levels of mlc2a, mlc2b, myogenin (myog), myostatin 1 (mstn1), mrf4, follistatin ( $f$ st), insulin-like growth factor 1 (igfl) and collagen lal (collal) were determined (Table 1). Real-time polymerase chain reaction (QPCR) was conducted in an MXPro 2000 (Stratagene) in duplicate by using the KAPA SYBR FAST qPCR (2×; KAPA Biosystems, KK4602). All reactions comprised 150$300 \mathrm{nmol} / \mathrm{l}$ of each primer and $0.17 \mu \mathrm{g} / \mu \mathrm{l} \mathrm{cDNA}$ (1:5 diluted) in a reaction volume of $20 \mu \mathrm{l}$. The following PCR conditions were used: an initial denaturation step at $95{ }^{\circ} \mathrm{C}$ for $3 \mathrm{~min}$, 40 cycles of amplification (each cycle was $30 \mathrm{~s}$ at $95^{\circ} \mathrm{C}$, $1 \mathrm{~min}$ at $61^{\circ} \mathrm{C}, 1 \mathrm{~min}$ at $72^{\circ} \mathrm{C}$ ), followed by the dissociation curve step $\left(1 \mathrm{~min}\right.$ at $95^{\circ} \mathrm{C}, 30 \mathrm{~s}$ at $55^{\circ} \mathrm{C}, 30 \mathrm{~s}$ at $\left.95^{\circ} \mathrm{C}\right)$ to verify the amplification of a single product. Efficiency curves were obtained for each cDNA template by plotting CT values against the $\log _{10}$ of six serial dilutions of a cDNA pool created from all samples analyzed. Q-PCR efficiency (E) was calculated according to $\mathrm{E}=10^{[-1 / \text { slope }]}$ (Pfaffl 2001) and varied between $95 \%$ and $100 \%$. A series of housekeeping genes (efl $\alpha, b$-actin, rpl13a, rps 18) were validated for use and were rated by using the geNorm VBA applet (Vandesompele et al. 2002). The normalization factor was calculated as the geometric mean of the three most stably expressed housekeeping genes (b-actin, rpl13 and efla).

\section{Statistical analyses}

Gene expression data were square-root-transformed to meet assumptions of normality and/or homogeneity. Morphometric and Q-PCR results are expressed as means \pm standard error of the mean (SEM). Morphometric data failed to fit the Kolmogorov-Smirnov test for normality and were analyzed by using a non-parametric Kruskal-Wallis analysis of variance median test (Zar 1996). When significant differences were obtained, a post-hoc non-parametric Dunn's test was used to determine the influence of age on larval development. The frequency distribution of $<5 \mu \mathrm{m}$ diameter of white muscle fibers was evaluated with Pearson's chi-squared test (Zar 1996). Spearman's rank correlation was performed to assess the statistical dependence of the two variables (Zar 1996). For all statistical tests, differences were considered to be significant 
Table 1 Gene identity, accession number and forward and reverse primers used for real-time polymerase chain reaction analysis of gene expression (efl $\alpha, b$-actin, rpll3a, rps 18 housekeeping genes, $m l c 2 a$ myosin light chain 2a isoform A, mlc2b myosin light chain 2a isoform B, myog myogenin, mstn 1 myostatin 1, mrf4 myogenic regulatory factor 4, $f_{s t}$ follistatin, igfl insulin-like growth factor 1, collal collagen 1a1)

\begin{tabular}{llll}
\hline Gene & Accession number & Forward primer & Reverse primer \\
\hline efla & AF184170 & TCAAGGGATGGAAGGTTGAG & AGTTCCAATACCGCCGAT \\
$r p l 13 a$ & AF384096 & CGACATCCGTAAGGACCTGT & ACATCTGCTGGAAGGTGGAC \\
$r p s 18$ & CV133427 & TCTGGAGGACTGTCAGGGGCATGC & AGACGCACAATCTTAAGAGCAG \\
$m l c 2 a$ & AM490061 & AGGGTGTTGGCAGACGTTAC & GAGGACCTGGCTGTATTTGC \\
$m l c 2 b$ & AF150904 & GCCCCATCAACTTCACCGTCTTT & GGTTGGTCATCTCCTCAGCGG \\
$m y$ og & EF46219629 & TCCCTTTGCTATTCTGCCTTC & AAATCAGCCCTATTCCCCATA \\
$m s t n 1$ & AF258448 & CAGAGGCTGCCCAAGGTG & CAGGTGCTGCCCGAACTGGGC \\
$m r f 4$ & N034421 & TTTTTGACACAACCGATCCA & GTGTGTGTGTTCCTGCATCC \\
st & AY544167 & AGCGGGGAKGAGCACGTCCT & ATGGCGCTGMGTAAAATCTCC \\
collal & AY 996779 & GTACCAGGGGAAGTGCAAGA & GCATAGATGATCCCGTCGTT \\
\hline
\end{tabular}

at $P<0.05$. Data were analyzed by using SigmaStat software (version 3.5; STATCON).

Supervised hierarchical clustering was applied (de Hoon et al. 2004) to Q-PCR analysis and each gene was classified according to its expression profile. TreeView software was used to generate a visual representation of the classification.

\section{Results}

\section{Larval growth, muscle growth and changes in muscle cellularity}

The axial growth of gilthead sea bream larvae recorded as total length was linear between $5 \mathrm{dph}$ and $60 \mathrm{dph}(P \leq 0.001$, Fig. 1). The TCSA of dorsal white muscle increased continuously during the period studied (Fig. 2a).

The TNF increased significantly between $15 \mathrm{dph}$ and 35 dph (from $250 \pm 34$ to $742 \pm 30$, mean \pm SEM) compared with

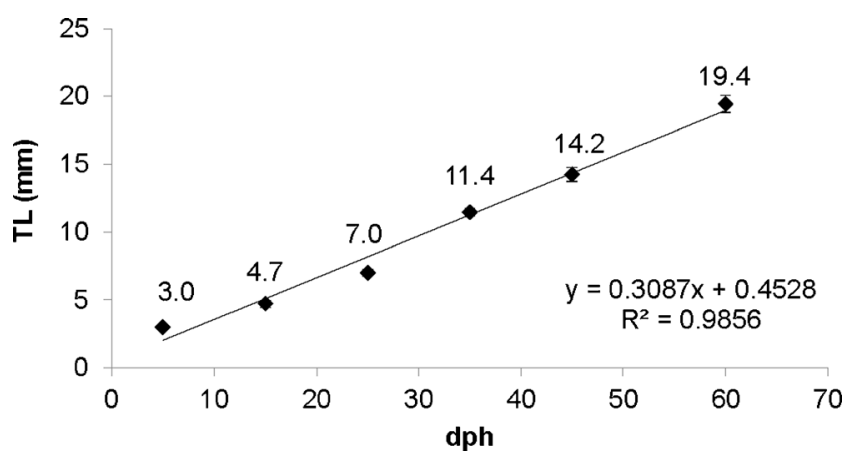

Fig. 1 Increase in total length $(T L ; \mathrm{mm})$ of gilthead sea bream larvae during the experiment ( $d p h$ days post hatch). Values are given as means \pm SEM $(n=10 /$ sample) other age groups and slowed down in subsequent stages $(P \leq$ 0.001 , Fig. 2b). The distribution of white muscle fiber diameter in all age groups was monophasic rather than biphasic and shifted to larger fibers with age increment (Fig. 3a). Hyperplasia was dominant between 15 and $25 \mathrm{dph}$ as revealed by the increase in TNF $(+109 \%)$ and the lack of differentiation in the distribution of muscle fiber diameter (Figs. 2b, 3a). As shown in Fig. 3b, hyperplasia was powered in these ages by germinal zones located at the myotome periphery. White muscle fibers with a diameter smaller than $5 \mu \mathrm{m}$ (WFD $<5 \mu \mathrm{m}$ ) increased from $34 \%$ in $15 \mathrm{dph}$ larvae to its maximum value of $40 \%$ in 25 dph larvae and decreased thereafter $(P \leq 0.001$, Fig. 4a). Mean WFD doubled from 25 to $35 \mathrm{dph}$ ( $P \leq 0.001$, Fig. 4b). Mean WFP and WFA did not change between 15 and $25 \mathrm{dph}$ but a significant progressive increase occurred thereafter (for both WFP and WFA, $P \leq 0.001$, not shown). Mean fiber diameter was well correlated with mean fiber area $(\mathrm{R}=1, P=$ 0.000), mean fiber perimeter $(\mathrm{R}=0.990, P=0.000)$ and fish total length $(\mathrm{R}=0.977, P=0.000)$ as indicated by the Spearman rank correlation.

In 35 dph larvae, white fiber size analysis revealed an overall increase relative to earlier stages (Fig. 3a) and we measured a four-fold increment in mean fiber area $(P \leq 0.001)$ and a twofold increase in mean diameter $(P \leq 0.001)$ and mean perimeter $(P \leq 0.001)$ compared with $25 \mathrm{dph}$ larvae. The germinal zones of small-diameter white fibers located at the myotome periphery were still evident but the percentage of white muscle fibers smaller than $5 \mu \mathrm{m}$ was significantly decreased $(P \leq 0.001$, Fig. 4a) compared with 25 dph larvae.

In 45 dph larvae, white muscle growth occurred principally by hypertrophy with a two-fold increase in mean area $(P \leq$ $0.001)$ and an overall significant increase in fiber mean diameter $(P \leq 0.001)$ and mean perimeter $(P \leq 0.001)$ compared with 


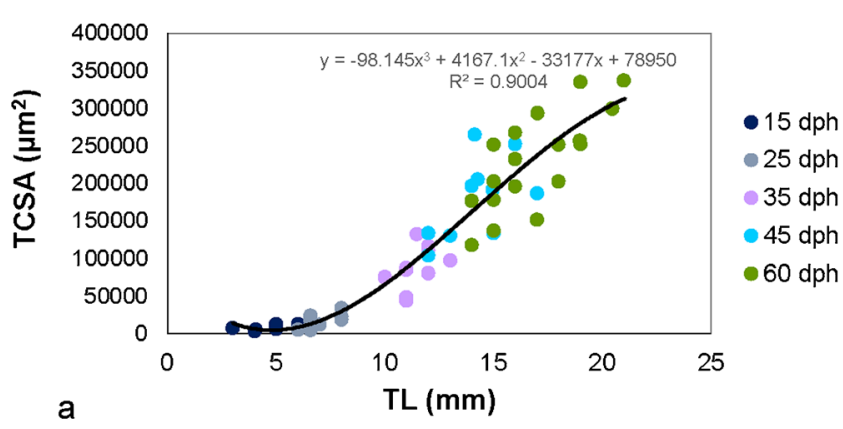

down-regulated $(P<0.001)$ relative to earlier stages but significantly increased again on $60 \mathrm{dph}$ at the onset of mosaic hyperplasia (Figs. 3b, 5a).

Isoform $m l c 2 b$ was of low abundance during early hyperplastic growth (5-25 dph) and was significantly up-regulated during hypertrophy (Fig. 5b). A transient down-regulation of $m l c 2 b$ expression occurred at $45 \mathrm{dph}$ before it peaked at 60 $\mathrm{dph}$, at the onset of mosaic hyperplasia. Expression of colla 1 (Fig. 5c) paralleled and was at similar levels to those of $m l c 2 b$. Expression of $m l c 2 b$ was significantly lower than $m l c 2 a$ at all sample times $(P<0.002)$, making $m l c 2 a$ the dominant isoform in early development. The expression of all three of the structural genes analyzed was significantly and positively correlated during gilthead sea bream early development $(P<0.05$, Table 2).

During early rapid hyperplasia $(5,15,25 \mathrm{dph})$, myog was highly expressed but was significantly down-regulated at 45 dph when the recruitment in apical germinal zones ceased $(P<0.001$, Fig. 6a). A significant positive and a significant negative correlation was observed between myog expression and the expression of $m l c 2 a$ and $m l c 2 b$, respectively. However, no correlation occurred between myog expression and $\mathrm{co}^{-}$ lla1 expression. A significant positive correlation was observed between myog expression and other important regulatory genes, namely $m s t n 1, f s t$ and igfl (Table 2).

Expression of $m r f 4$ remained at low levels until $15 \mathrm{dph}$ when a peak in its expression that coincided with the establishment of apical germinal zones and the accumulation of newly formed fibers occurred ( $P=0.02$, Fig. $6 \mathrm{~b}$ ). The expression of $m r f 4$ was negatively correlated with all the other genes studied but the correlation was only significant with mstn 1 (Table 2).

Expression of $m s t n 1$ (Fig. 6c) and igfl (Fig. 6e) was at low levels up until $25 \mathrm{dph}$. Subsequently, expression increased with a transient peak occurring at $35 \mathrm{dph}$ and coinciding with the increase in mean fiber diameter and was significantly positively correlated with the transcript abundance of $m l c 2 a$ and collal (Table 2). In contrast, $f_{s t}$ was highly abundant at 5 $\mathrm{dph}$ and declined progressively during the development of the muscle ( $P \leq 0.001$, Fig. 6d). Interestingly, $f_{s t}$ exhibited a significant negative correlation with all three structural genes (Table 2).

\section{Hierarchical gene clustering}

The expression of structural genes and of myogenic and hormonal factors was monitored by Q-PCR in age classes of sea bream larvae in which substantial cellular changes were observed by histology. The most abundant isoform of $m l c 2$ during stratified hyperplasia was $m l c 2 a$ and its expression significantly $(P<0.001)$ increased by 2.4 -fold between $25 \mathrm{dph}$ and 35 dph (Fig. 5a). Indeed, TNF reached its maximum (742 \pm 94 ; mean \pm SEM) at 35 dph relative to other age classes. After $35 \mathrm{dph}$, when dorsal and ventral germinal zones contained few small-diameter fibers, $m l c 2 a$ was significantly

Hierarchical clustering was performed on the mean expression levels of the eight genes studied (Fig. 7). Genes were clustered on the basis of the similarity of their expression during sea bream larval development. Two major clusters were found (Fig. 7): cluster I contained all the genes that were significantly up-regulated at the onset of hypertrophy at $35 \mathrm{dph}$ ( $\mathrm{mlc} 2 a$, $m l c 2 b$, colla $1, m s t n 1$ and $i g f 1)$. All structural genes fell within cluster I. Comparison of the expression levels of genes in 
Fig. 3 a Changes in the distribution of white muscle fiber diameter in an epaxial white muscle quadrant of gilthead sea bream larvae at 15, 25, 35, 45 and $60 \mathrm{dph}$. b View of the anatomical position of the muscle fibers according to their diameter (smallest fibers in violet, largest in fuchsia)
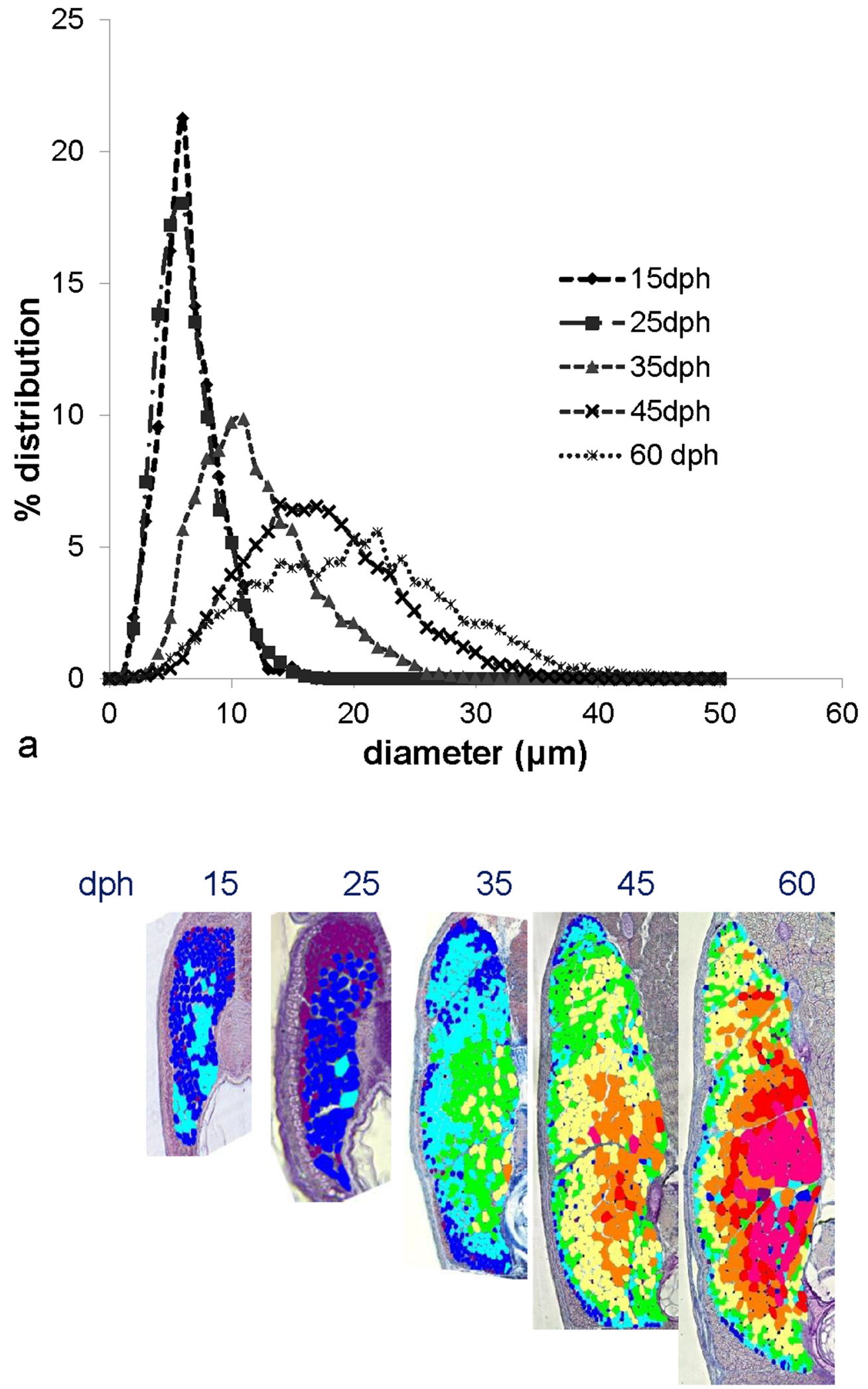

b

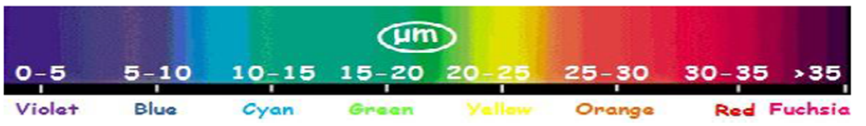



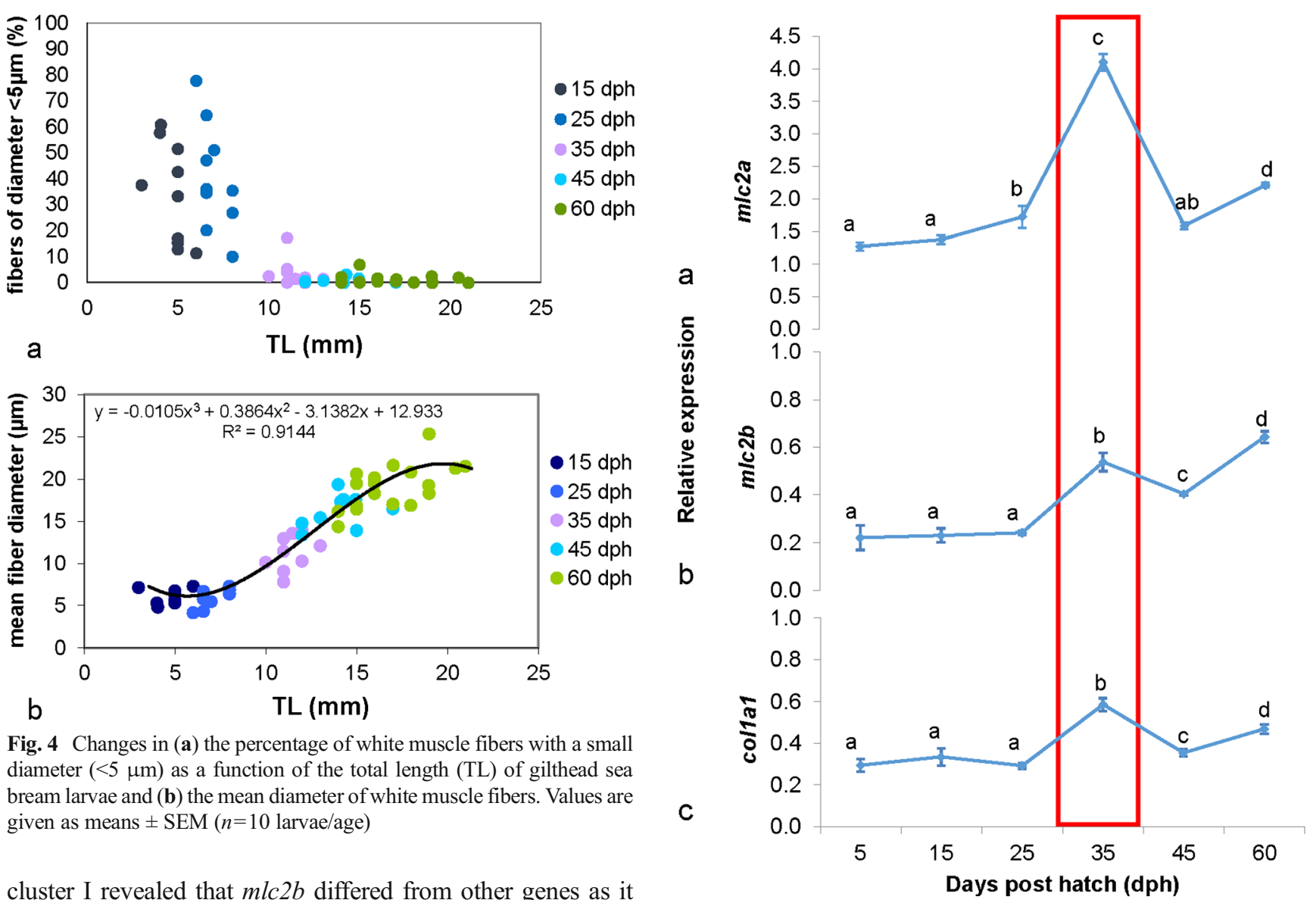

cluster I revealed that $m l c 2 b$ differed from other genes as it exhibited the highest expression on $60 \mathrm{dph}$ and marked the initiation of mosaic hyperplasia during sea bream muscle development. Genes of cluster I went through a transitional phase of decreased expression at $45 \mathrm{dph}$ between the initiation of hypertrophy ( $35 \mathrm{dph}$ ) and the initiation of mosaic hyperplasia $(60 \mathrm{dph})$. Cluster II contained genes highly expressed before muscle hypertrophy (myog, fst, mrf4; Fig. 7). The expression of all genes of cluster II declined significantly as muscle development progressed.

\section{Discussion}

In the gilthead sea bream, the early stages in the development of muscle are a crucial period and the fine implementation of hyperplastic and hypertrophic mechanisms is a prerequisite for the successful transition from larvae to juveniles. The present study offers insight into the molecular mechanisms involved in the onset of hypertrophy and mosaic hyperplasia by following the expression patterns of key structural and regulatory genes in these larvae from $5 \mathrm{dph}$ to $60 \mathrm{dph}$. Our comparison of the gene expression patterns with the changes observed in muscle cellularity revealed significant regulatory contributions to the transitional stages. The expression of $m l c 2 a$ dominates these early stages and marks the formation of new fibers, whereas $m l c 2 b$ is up-regulated at the onset of

Fig. 5 Expression patterns of structural genes ( $m l c 2 a$ myosin light chain $2 \mathrm{a}$ isoform $\mathrm{A}, m l c 2 b$ myosin light chain $2 \mathrm{a}$ isoform $\mathrm{B}$, coll al collagen 1a1) in developing gilthead sea bream larvae; (a) $m l c 2 a$, (b) $m l c 2 b$, (c) collal. Values are given as means of normalized arbitrary expression levels of 10 larvae/age. Values with the same superscript are not significantly different at $P<0.05$. Red box indicates the onset of hypertrophy

hypertrophy. Interestingly, $m s t n 1$ appears to be associated with the onset of hypertrophy together with igfl and they may act as molecular triggers for the expression of the structural factors $m l c 2 a, m l c 2 b$ and colla1 at mosaic hyperplasia post-metamorphosis.

\section{Gilthead sea bream early development and changes in muscle growth dynamics}

Many developmental changes that occurred in gilthead sea bream during the period of the study are linked to changing function (Patruno et al. 1998). Larvae first attempt to feed with active darting movements between $1 \mathrm{dph}$ and $9 \mathrm{dph}$ (i.e., between 15 degree-days post hatch $\left[{ }^{\circ} \mathrm{dph}\right]$ and $135^{\circ} \mathrm{dph}$, with an experimental temperature of $15^{\circ} \mathrm{C}$ up to $20^{\circ} \mathrm{dph}$ and $17-18{ }^{\circ} \mathrm{C}$ thereafter); their gut development progresses and they show active feeding and continuous eel-like swimming plus darting movements between $9 \mathrm{dph}$ and $18 \mathrm{dph}\left(135-270^{\circ} \mathrm{dph}\right)$. The 
Table 2 Spearman rank correlation coefficients between structural (shaded) genes and myogenic and regulatory factors in developing gilthead sea bream larvae. $* P<0.05 ; * * P<0.01 ; * * * P<0.001$

\begin{tabular}{|c|c|c|c|c|c|c|c|}
\hline & $m / c 2 b$ & $c o l 1 a 1$ & $m r f 4$ & $m y o g$ & $m s t n 1$ & $f s t$ & $i g f 1$ \\
\hline$m / c 2 a$ & $0.649^{* * *}$ & $0.716^{* * *}$ & -0.136 & $0.318^{*}$ & $0.723^{* * *}$ & $-0.305^{*}$ & $0.557^{*}$ \\
\hline$m / c 2 b$ & - & $0.583^{* * *}$ & -0.074 & $-0.287^{* *}$ & $0.591^{* * *}$ & $-0.455^{* * *}$ & -0.023 \\
\hline col1a1 & & & -0.062 & -0.007 & $0.700^{* * *}$ & $-0.230^{*}$ & $0.367^{*}$ \\
\hline$m r f 4$ & - & & - & -0.017 & $-0.208^{*}$ & -0.195 & -0.188 \\
\hline$m y o g$ & - & - & - & - & $0.366^{*}$ & $0.527^{* * *}$ & $0.435^{*}$ \\
\hline$m s t n 1$ & - & & & - & & -0.038 & $0.507^{* * *}$ \\
\hline$f s t$ & - & & - & - & - & & 0.114 \\
\hline
\end{tabular}

flexion of the notochord, a major event in larval development, is in progress at $18 \mathrm{dph}$ and is completed by 30-45 dph (475$738^{\circ} \mathrm{dph}$ ) allowing combined eel-like and hydrofoid swimming. Metamorphosis ends before $60 \mathrm{dph}\left(1000^{\circ} \mathrm{dph}\right)$, as fish aged 60 dph lose their typical larval features (Patruno et al. 1998).

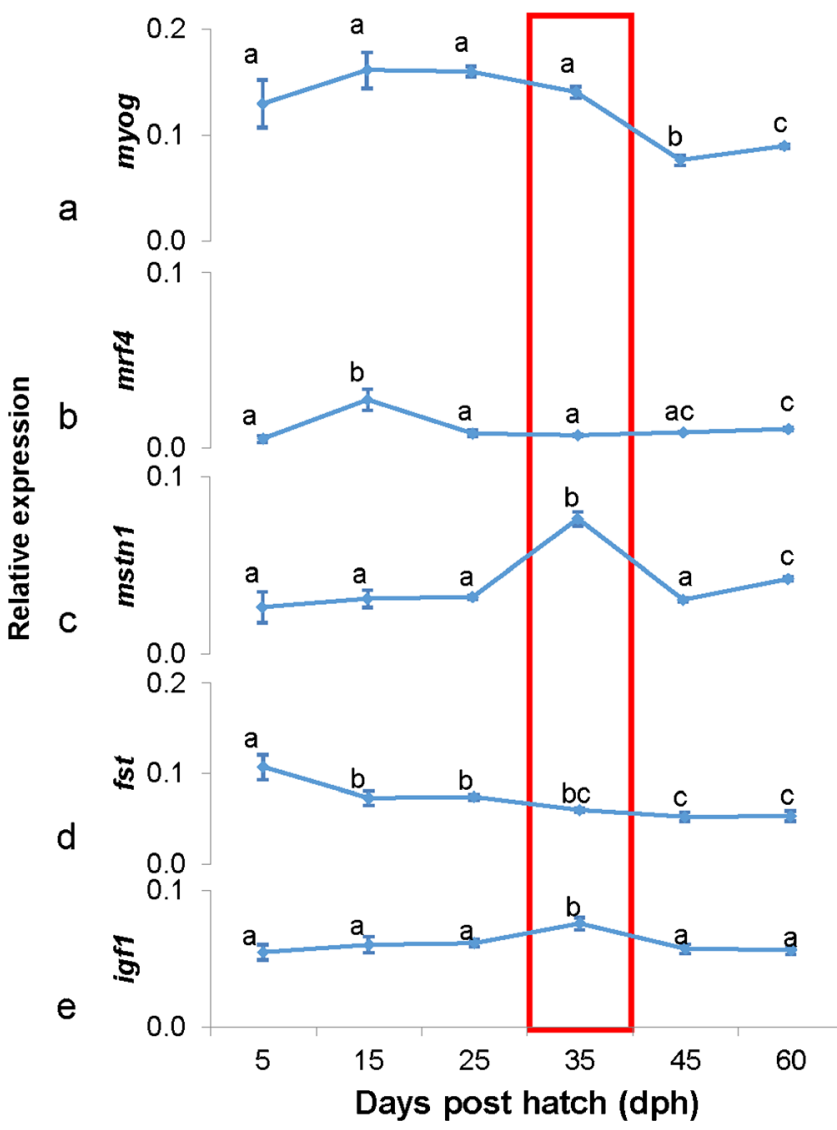

Fig. 6 Expression patterns of myogenic and regulatory genes (myog myogenin, mrf4 myogenic regulatory factor $4, m s t n 1$ myostatin 1 , fst follistatin, igf1 insulin-like growth factor 1) in developing gilthead sea bream larvae; (a) myog, (b) $m r f 4$, (c) $m s t n 1$, (d) $f s t$, (e) igfl. Values are given as means of normalized arbitrary expression levels of 10 larvae/age. Values with the same superscript are not significantly different at $P<0.05$. Red box indicates the onset of hypertrophy

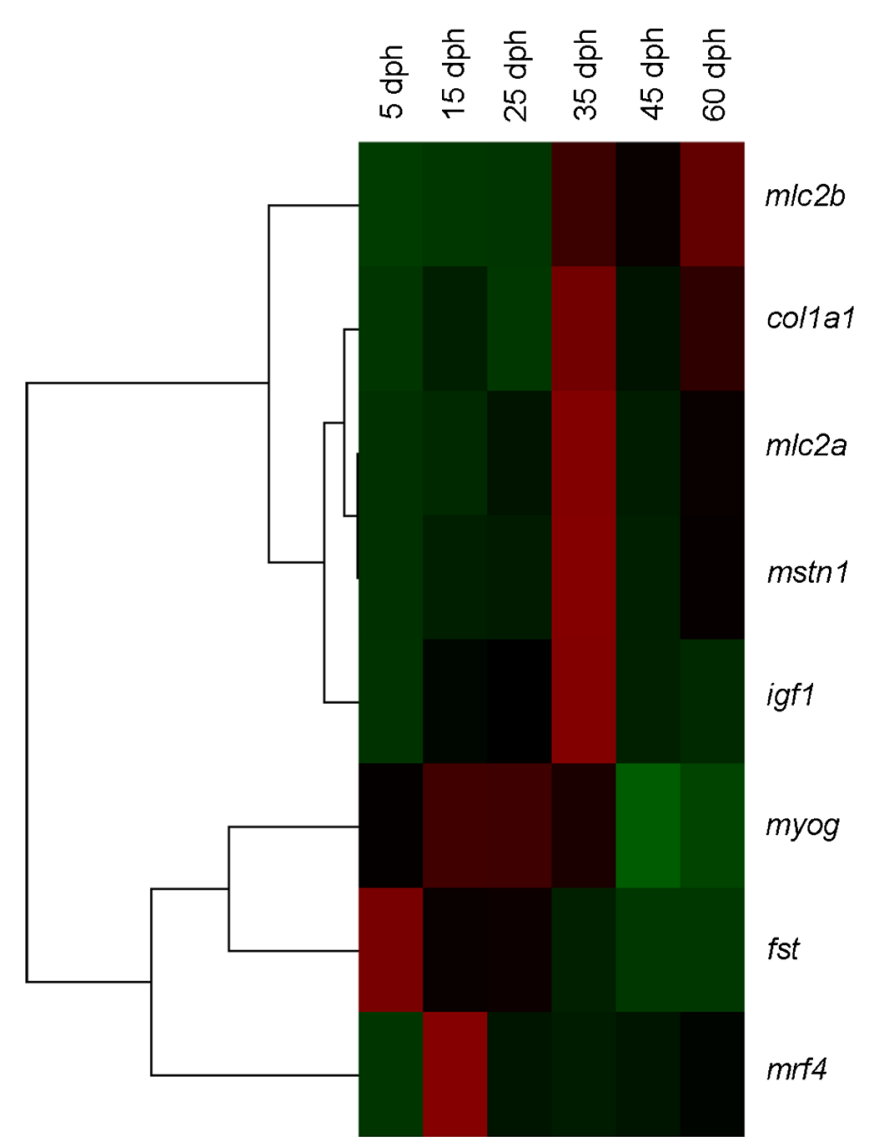

Fig. 7 Hierarchical clustering of the eight target genes during gilthead sea bream larval development. Gene clustering is based on transcript expression levels. The different ages of sea bream larvae ( $d p h$ days post hatch) that were used in the analysis are represented in columns, whereas the various genes are represented in rows. Relative abundance of each transcript across the different ages is represented by a color scale: red and green indicate an increase and a decrease in mean gene expression level compared with an initial level of expression from $5 \mathrm{dph}$ to $60 \mathrm{dph}$, respectively, whereas black indicates no change ( $m l c 2 a$ MLC2 isoform $\mathrm{A}$, mlc $2 b$ MLC2 isoform B, myog myogenin, mstn1 myostatin 1, collal collagen 1a1, fst follistatin, igfl insulin-like growth factor 1, mrf4 myogenic regulatory factor 4 ) 
Muscle cellularity reflects the collective activity of various growth mechanisms that result in the accumulation of structural muscle proteins. The total muscle fiber number has been tightly linked to the final size that fish attain and to their growth potential in the wild and under farmed conditions (Weatherley et al. 1988; Pitkänen et al. 2001; Johnston et al. 2004). The mechanisms that lead to muscle fiber formation during the early developmental stages of fish alter; the programs of embryonic muscle development are succeeded by stratified hyperplasia in larvae and mosaic hyperplasia takes over in juveniles (Rowlerson and Veggetti 2001 and references therein). The period following hatching is marked by dramatic hyperplastic growth with the formation of new fibers in apical dorsal and ventral muscle germinal zones. This pattern of development has previously been described in gilthead sea bream (Ramírez-Zarzosa et al. 1995; Rowlerson et al. 1995; Patruno et al. 1998) and has been confirmed in the present study.

Myotomal muscle consists of a superficial red muscle layer and underlying deep white muscle fibers. The cellularity of the dorsal epaxial white muscle differs significantly between early stages and hyperplasia is the predominant mechanism of muscle growth up until $25 \mathrm{dph}\left(475^{\circ} \mathrm{dph}\right)$. Between 25 and $35 \mathrm{dph}$ $\left(665^{\circ} \mathrm{dph}\right)$, hypertrophic growth is initiated and marks a transition state when both hyperplasia and hypertrophy occur. A pause in fiber formation has been recorded by $45 \mathrm{dph}$ $\left(855^{\circ} \mathrm{dph}\right)$ and hypertrophy becomes the main mechanism of muscle growth. Then, at $60 \mathrm{dph}\left(1140^{\circ} \mathrm{dph}\right)$, the recruitment of white muscle fibers is observed in the deep white muscle. This new phase of hyperplasia, powered by deep muscle precursor cells, was not detected in sea bream at $1000^{\circ} \mathrm{dph}$ by Rowlerson et al. (1995) but occurs at $1525^{\circ} \mathrm{dph}$. In the latter work, no significant increase in mean fiber area was reported up until $755^{\circ} \mathrm{dph}$, contrary to the present study in which high hypertrophic activity was observed from $25 \mathrm{dph}$ $\left(475^{\circ} \mathrm{dph}\right)$ onwards. Furthermore, Rowlerson et al. (1995) reported a much lower percentage of fibers with a diameter $<$ $5 \mu \mathrm{m}$ at $225^{\circ} \mathrm{dph}(20 \%)$ and $405^{\circ} \mathrm{dph}(9 \%)$, than in the present study ( $34 \%$ at $285^{\circ} \mathrm{dph}$ and $40 \%$ at $475^{\circ} \mathrm{dph}$ ). The discrepancies in the chronology and intensity of hyperplasia and hypertrophy between the present study and that of Rowlerson et al. (1995) are difficult to explain but might arise from factors such as genetic background, feeding scheme, dietary composition and temperature $\left(15-18^{\circ} \mathrm{C}\right.$ vs $19^{\circ} \mathrm{C}$ constant). Temperature accounts probably for a great part of the observed differences between the studies, because the pace of both hyperplastic and hypertrophic growth and the resulting muscle cellularity are known to be highly affected by temperature during incubation and larval rearing (Alami-Durante et al. 2000, 2006; Johnston et al. 1995, 2000). The present study revealed that the total number of white muscle fibers is not directly and linearly correlated to larval axial growth in the early stages of gilthead sea bream. We found that small-diameter white fibers $(<5 \mu \mathrm{m})$, indicative of new fiber formation (Rowlerson et al. 1995), constitute the germinal zones at the myotome edge from $15 \mathrm{dph}$ to $35 \mathrm{dph}$ (285$665^{\circ} \mathrm{dph}$ ) but that new white muscle fiber formation in this zone is more pronounced between 15 and 25 dph (285$\left.475^{\circ} \mathrm{dph}\right)$. The stage at $35 \mathrm{dph}\left(665^{\circ} \mathrm{dph}\right)$ is most likely intermediate in gilthead sea bream development as muscle growth is attributable not only to hyperplasia but also to hypertrophy. This new process in muscle growth thus begins during the developmental window $\left(475-665^{\circ} \mathrm{dph}\right)$ during which, according to Patruno et al. (1998), another major event in gilthead sea bream early development occurs, i.e., the complete flexion of the notochord. From $35 \mathrm{dph}$ to $45 \mathrm{dph}\left(665-855^{\circ} \mathrm{dph}\right)$, no addition of new white muscle fibers was seen to occur in the present study and by $45 \mathrm{dph}$, the stratification phase of muscle growth had come to an end.

Stratified muscle growth has been observed prior to, or at the onset of first feeding and prevails until the start or the end of metamorphosis of several marine fish species such as sea bass (Dicentrarchus labrax, Veggetti et al. 1990; AlamiDurante et al. 1997), Atlantic cod (Gadus morhua, Galloway et al. 1999a), Atlantic halibut (Hippoglossus hippoglossus, Galloway et al. 1999b; Campinho et al. 2007), European plaice (Pleuronectes platessa, Brooks and Johnston 1993), Senegalese sole (Solea senegalensis, Campos et al. 2013), common sole (Solea solea, Veggetti et al. 1999), turbot (Scophthalmus maximus, Calvo and Johnston 1992; Gibson and Johnston 1995) and cyprinids (Chalcalburnus chalcoides mento, Rutilus frisii meidingeri, Rutilus rutilus, Stoiber and Sanger 1996; Cyprinus carpio, Alami-Durante et al. 1997). Patruno et al. (1998) suggested that $60 \mathrm{dph}\left(1140^{\circ} \mathrm{dph}\right.$ in the present study; $1000^{\circ} \mathrm{dph}$ in the studies of Rowlerson et al. 1995) represents a true juvenile post-larval stage reached after metamorphosis, i.e., after the loss of larval features. Deep muscle progenitor cells (satellite cells) are known to be recruited in gilthead sea bream juveniles (Rowlerson et al. 1995; Patruno et al. 1998); these new small-diameter fibers arise between the mature white fibers and give it a mosaic transversal appearance. Our results suggest that this mosaic recruitment begins early during gilthead sea bream juvenile life, as soon as $60 \mathrm{dph}\left(1140^{\circ} \mathrm{dph}\right)$. This recruitment of deep muscle precursor cells is a characteristic feature of species that attain a large final size (Rowlerson and Veggetti 2001). According to Weatherley et al. (1988), this fiber input proceeds until the fish achieve 40-45\% of their definite TL. However, the current experimental design did not allow for such an observation in gilthead sea bream.

\section{Gene expression and muscle development}

The larval to adult transition appears well orchestrated in white muscle of gilthead sea bream larvae at the molecular level. The results of the present study suggest that the two 
isoforms of MLC2 are under differential developmental regulation with increasing expression of $m l c 2 a$ in pre-metamorphic stages and during new fiber formation (between 15 and 25 $\mathrm{dph}$ ). In the present study, a significant increase in $m l c 2 b$ expression marked the onset of hypertrophy (between 25 and 35 $\mathrm{dph}$ ) and mosaic hyperplasia (between 45 and $60 \mathrm{dph}$ ). In addition, another recent study in gilthead sea bream showed that $m l c 2 b$ expression continued increasing in the post-larval stages (55-117dph), whereas $m l c 2 a$ expression dropped to low levels (Georgiou et al. 2014). Thus, MLC2B becomes the predominant isoform in adult muscle fibers in gilthead sea bream and its expression is significantly correlated to length growth (Georgiou et al. 2014). An early preliminary study on the developmental expression of $m l c 1$ and $m l c 2$ in gilthead sea bream by in situ hybridization showed that $m l c 2$ expression marked the germinal zones of skeletal muscle and the newly formed white fibers, whereas in juveniles, its expression was restricted to myogenic cells interspersed in the fast white muscle (Moutou et al. 2005). In a following study (Sarropoulou et al. 2006), it became evident that two mlc2 isoforms existed, namely $m l c 2 a$ and $m l c 2 b$; the study by Moutou et al. (2005) referred only to $m l c 2 a$, the only known $m l c 2$ at the time. A plausible mechanism that combines the results of all studies so far is that MLC2A is the isoform expressed in the newly formed fibers and that it is replaced by MLC2B when muscle fibers reach some critical size.

The pattern of expression of collal was similar to that of $m l c 2 b$ to support the hypertrophic growth of muscle mass. The rise in collal expression at $35 \mathrm{dph}$ was consistent with earlier results in the gilthead sea bream, in which collal expression was low up to $29 \mathrm{dph}$ and was significantly upregulated between 29-37 dph (Fernández et al. 2011). A similar expression pattern was also observed during European sea bass development whereby collal expression was positively correlated with bone development (Darias et al. 2008) suggesting that collal is of huge biological importance by providing mechanical support in both the growing skeleton and the increasing muscle fiber organization.

Muscle differentiation is a complex process that requires the combined action of certain transcription factors, the myogenic regulatory factors (MRFs), the expression of which is finely regulated both temporally and spatially (Ferri et al. 2009). The transcription, subcellular localization and protein half-life of MyoD, Myf5, myogenin and MRF4 appear to be tightly regulated to ensure myogenic determination, proliferation and myotube differentiation (Zhang et al. 1995; KassarDuchossoy et al. 2004; Ishibashi et al. 2005; Patterson et al. 2008; Ferri et al. 2009). Myogenin and MRF4 are factors that govern the middle and terminal differentiation phases and that orchestrate the expression of the muscle-specific genes including those encoding the contractile proteins (Sánchez and Robbins 1994; Blais et al. 2005). In the present study, myog was expressed at highest levels during the formation of new fibers up to $35 \mathrm{dph}$ and then declined to lower levels together with $m l c 2 a$. The results of the present study are in agreement with our previous study of developing gilthead sea bream larvae and primary muscle cell cultures and with the results from studies of other organisms that indicate that myogenin is an important regulator of muscle differentiation (Dedieu et al. 2002; Cao et al. 2006; Ferri et al. 2009; Moutou et al. 2009). Cumulative data point to its crucial role in terminal differentiation and the control of synthesis of the proteins of the contractile apparatus (Blais et al. 2005). Studies in C2C12 cells have shown that myogenin is expressed even in undifferentiated cells in which it is restricted to the cytoplasm. Only after the induction of differentiation is it translocated into the nucleus to exert its action (Ferri et al. 2009). This pattern is consistent with its high expression levels as early as $5 \mathrm{dph}$ in gilthead sea bream when proliferation of small fibers prevails. The significant positive correlation between the expression of myog and transcripts of $m l c 2 a$, both of which are elevated during the phase of intensive formation of new fibers, suggests that they are good candidate markers of hyperplasia. Myogenin might drive $m l c 2 a$ gene expression through the putative binding sites for the members of the basic helixloop-helix (bHLH) family myogenic regulatory factors, which are present in the $m l c 2 a$ gene promoter (Funkenstein et al. 2007). The significant rise in $m r f 4$ expression on $15 \mathrm{dph}$ is indicative of its role in determination rather than in differentiation; this is in agreement with the contemporary hypothesis that MyoD, Myf5 and MRF4 define muscle identity and that muscle differentiation is driven by MyoD, myogenin and MRF4 (Kassar-Duchossoy et al. 2004; Ferri et al. 2009). Nonetheless, the relative expression levels of the myogenic factors MRF4 and myogenin resemble the patterns reported in differentiating $\mathrm{C} 2 \mathrm{C} 12$ cells with myogenin being the most abundantly expressed myogenic factor (Ferri et al. 2009).

Myostatin is considered to be an inhibitor of proliferating myoblasts and a major negative regulator of fiber number (Ostbye et al. 2001). Two mstn paralogs have been identified in gilthead sea bream, namely $m s t n 1$ and $m s t n 2$ (Maccatrozzo et al. 2001a, 2001b; Nadjar-Boger and Funkenstein 2011). The gene mstnl is predominantly expressed in muscle and mstn1 gene polymorphism has been associated with growth traits (Sánchez-Ramos et al. 2012). Consistent with its inhibitory role in growth, $m s t n 1$ expression has previously been reported to be low in gilthead sea bream during the early developmental stages ( 1 to $44 \mathrm{dph}$; Maccatrozzo et al. 2001a). In the current study, however, mstn1 had the same expression pattern as $m l c 2 b$ and increased its expression significantly to peak on $35 \mathrm{dph}$ (Fig. 6c), suggesting a possible role in regulating the shift from stratified hyperplasia to hypertrophy. A similar pattern has been reported in $\mathrm{C} 2 \mathrm{C} 12$ cells with MSTN being detected in the myotubes but not in the myoblasts (Artaza et al. 2002) in which its up-regulation is initiated with nuclei accretion. Two distinct phases in $m s t n 1$ 
expression have also been detected in European sea bass (Dicentrarchus labrax) in which mstn1 expression remains at low levels up to $10 \mathrm{dph}$ to subsequently exhibit a rapidly increasing expression between 10 and $40 \mathrm{dph}$. Interestingly, $m s t n 1$ expression at the pre-metamorphotic stages is localized in the apical proliferation zones, whereas post-metamorphosis, it is restricted to the proliferative zone adjacent to the horizontal septum (Patruno et al. 2008). In gilthead sea bream larvae, $m s t n 1$ expression peaks at the same time as that of igfl (35 dph), suggesting that the combination of these two growth factors is associated with the end of muscle stratified hyperplasia and the switch to fiber hypertrophy. The strong correlation of mstn1 and igf1 (Table 2) reinforces their possible in vivo synergistic action. This is consistent with results showing that human MSTN inhibits the proliferation of cultured rainbow trout myoblasts only under IGF stimulation (Seiliez et al. 2012). It is tempting to speculate that the increase in mstn 1 and igfl expression between $25 \mathrm{dph}$ and $35 \mathrm{dph}$ in sea bream larvae acts as a signal to stop muscle stratified hyperplasia and that the decrease in $m s t n 1$ expression between $35 \mathrm{dph}$ and $45 \mathrm{dph}$ permits the hypertrophic growth of muscle fibers. Stage-specific MSTN expression overlaps with strong up-regulation of the major myosin heavy chain isoform MHC-II and to a lesser degree with MHC-I in $\mathrm{C} 2 \mathrm{C} 12$ cells (Artaza et al. 2002). A similar phenomenon was observed in the present study as based on the similarity of the expression pattern of mstn 1 clustered with structural genes (Fig. 7). Overall the results of the present study indicate that myostatin has a versatile regulatory action during sea bream ontogeny.

Myostatin action is antagonized by FST in mammals and chicks and several observations have connected FST to positive muscle growth (Matzuk et al. 1995; Lee and McPherron 2001; Amthor et al. 2004). A similar antagonistic MSTN/FST interaction has been shown in gilthead sea bream with the use of recombinant saFST over saMSTN activity in a reporter gene assay (Rebhan and Funkenstein 2008; Funkenstein et al. 2009). In adult sea bream tissues, $f_{s t}$ is expressed at higher levels than $m s t n 1$ and its expression is detectable before hatch at 15-16 h post fertilization (Funkenstein et al. 2009). The expression patterns of $f_{s t}$ and $m s t n l$ in the present study are in agreement with the results of a previous study with larvae up to $10 \mathrm{dph}$ (Funkenstein et al. 2009). The present study extended the temporal observations and revealed that $f_{s t} t$ expression declines slowly up to metamorphosis, and that $f_{s t}$ is significantly and negatively correlated with $m s t n 1$ expression but positively correlated with myog expression (Table 2). Thus, FST appears negatively to interact with MSTN-1 in vivo and it is associated more with the hyperplastic than the hypertrophic phase. FST-driven hyperplasia has also been observed in transgenic rainbow trout overexpressing FST. Transgenic trout exhibit a general increase in muscle mass accompanied by a new fiber formation and an increase in total fiber number and in the total crosssectional area (Medeiros et al. 2009).

IGF-1 is a molecule with a pleiotropic action in gilthead sea bream and appears to mediate the effects of growth hormone in seasonal growth, to have a pivotal role in compensatory growth following starvation, to induce osteoblast and myoblast proliferation in primary cell cultures and to increase glucose and amino acid uptake in cultured myoblasts through both MAPK and PI3K-Akt signal transduction pathways (Mingarro et al. 2002; Montserrat et al. 2007; Capilla et al. 2011; Rius-Francino et al. 2011; Montserrat et al. 2012). Igf1 transcripts have been detected in unfertilized gilthead sea bream eggs and its later expression appears to be tissue- and age-dependent, with skeletal muscle displaying high immunoreactivity (Perrot et al. 1999). In Atlantic salmon, increased igfl expression marks the transition from zero to fast growth and is followed by the increased expression of myosin genes including $m l c 2$ (Bower et al. 2008). Three alternatively spliced transcripts of igfl have been isolated in the gilthead sea bream (Tiago et al. 2008) and each has a distinct expression pattern during development. The primers used in the present study were designed to amplify all three igfl transcripts collectively. The stability in total igfl transcripts from 5 to $25 \mathrm{dph}$ in the present study is consistent with the findings of Fernandez et al. (2011) in the same species from $2 \mathrm{dph}$ to $29 \mathrm{dph}$. However, whereas these authors reported that igfl expression increases significantly between 29 and $45 \mathrm{dph}$ and between 52 and $60 \mathrm{dph}$, our findings demonstrate that igf 1 increases significantly only between 25 and $35 \mathrm{dph}$ and then decreases to the level observed at the beginning of the study. A third pattern of developmental regulation was founded by Tiago et al. (2008), with expression of the two main transcripts of igfl in gilthead sea bream larvae (igflc and igfla) decreasing significantly from 48 to $67 \mathrm{dph}$. Further studies are needed to elucidate the cause of the discrepancies between the studies. However, the patterns of igfl expression during development vary between species; in European sea bass larvae, igfl expression increases continuously up to 25 dph and remains at steady levels to $80 \mathrm{dph}$ (Patruno et al. 2008), whereas in shi drum (Umbrina cirrosa), it exhibits a transient increase at $15 \mathrm{dph}$ to decrease back to low levels by 19 dph (Patruno et al. 2006). In the present study, igfl expression was shown to be significantly and positively correlated with the expression of the $m l c 2 a$ and collal structural genes, with the expression of myog that manifests involvement in terminal differentiation and hypertrophic growth and with the expression of mstn 1 thus adding further support to the proposed dual role of igfl and myostatin in muscle growth.

In conclusion, myog accompanies a new fiber formation and $m \sin 1$ appears to regulate the hyperplasia-tohypertrophy transition, is probably the molecular trigger that stimulates the expression of the structural factors $m l c 2 a$, $m l c 2 b$ and collal at $60 \mathrm{dph}$ and is associated with a new phase 
of fiber formation. In early development (15-25 dph), when hyperplasia is high, myogenin has a more prominent role in muscle differentiation and presumably acts with MRF4 with which it clusters (Fig. 7). Later in development, when new fibers appear (60 dph), up-regulation of $m l c 2 a, m l c 2 b$ and collal occurs, all of which encode structural proteins essential for the building of muscle fibers. This fine tuning is reflected in the strong correlations (Table 2) and the gene hierarchical clustering in which structural genes form a single large cluster with igfl and $m s t n 1$ (Fig. 7). As the hyperplastic process initiated at $60 \mathrm{dph}$ is accompanied by the increase in expression of some of the genes analyzed, the present study provides insight into the molecular onset of mosaic hyperplasia.

Acknowledgments The authors thank M. Cluzeaud and D. Bazin for their technical support.

\section{References}

Abramoff MD, Magalhaes PJ, Ram SJ (2004) Image processing with ImageJ. Biophoton Internat 11:36-42

Alami-Durante H (1990) Growth of organs and tissues in carp (Cyprinus carpio L.) larvae. Growth Dev Aging 54:109-116

Alami-Durante H, Fauconneau B, Rouel M, Escaffre AM, Bergot P (1997) Growth and multiplication of white skeletal muscle fibres in carp larvae in relation to somatic growth rate. J Fish Biol 50: 1285-1302

Alami-Durante H, Bergot P, Rouel M, Goldspink G (2000) Effects of environmental temperature on the development of the myotomal white muscle in larval carp (Cyprinus carpio L.). J Exp Biol 203: 3675-3688

Alami-Durante E, Rouel M, Kentouri M (2006) New insights into temperature-induced white muscle growth plasticity during Dicentrarchus labrax early life: a developmental and allometric study. Mar Biol 149:1551-1565

Alami-Durante H, Olive N, Rouel M (2007) Early thermal history significantly affects the seasonal hyperplastic process occurring in the myotomal white muscle of Dicentrarchus labrax juveniles. Cell Tissue Res 327:553-570

Alami-Durante H, Médale F, Cluzeaud M, Kaushik SJ (2010a) Skeletal muscle growth dynamics and expression of related genes in white and red muscles of rainbow trout fed diets with graded levels of a mixture of plant protein sources as substitutes for fishmeal. Aquaculture 303:50-58

Alami-Durante H, Wrutniak-Cabello C, Kaushik SJ, Médale F (2010b) Skeletal muscle cellularity and expression of myogenic regulatory factors and myosin heavy chains in rainbow trout (Oncorhynchus mykiss): effects of changes in dietary plant protein sources and amino acid profiles. Comp Biochem Physiol 156A:561-568

Alami-Durante H, Cluzeaud M, Bazin D, Mazurais D, ZamboninoInfante JL (2011) Dietary cholecalciferol regulates the recruitment and growth of skeletal muscle fibers and the expressions of myogenic regulatory factors and the myosin heavy chain in European sea bass larvae. J Nutr 141:2146-2151

Alami-Durante H, Cluzeaud M, Duval C, Maunas P, Girod-David V, Medale F (2014) Early decrease in dietary protein/energy ratio by fat addition and ontogenetic changes in rainbow trout muscle growth mechanisms: short- and long-term effects. Br J Nutr 112:674-687, doi:10.1017/S0007114514001391
Amthor H, Nicholas G, McKinnell I, Kemp CF, Sharma M, Kambadur R, Patel K (2004) Follistatin complexes myostatin and antagonises myostatin-mediated inhibition of myogenesis. Dev Biol 270:19-30

Artaza JN, Bhasin S, Mallidis C, Taylor W, Ma K, Gonzalez-Cadavid N (2002) Endogenous expression and localization of myostatin and its relation to myosin heavy chain distribution in $\mathrm{C} 2 \mathrm{C} 12$ skeletal muscle cells. J Cell Physiol 190:170-179

Betancor MB, Izquierdo M, Terova G, Preziosa E, Saleh R, Montero D, Hernández-Cruz CM, Caballero MJ (2013) Physiological pathways involved in nutritional muscle dystrophy and healing in European sea bass (Dicentrarchus labrax) larvae. Comp Biochem Physiol 164A:399-409

Blais A, Tsikitis M, Acosta-Alvear D, Sharan R, Kluger Y, Dynlacht BD (2005) An initial blueprint for myogenic differentiation. Genes Dev 19:553-569

Bone Q (1978) Locomotor muscle. In: Hoar WS, Randall DJ (eds) Fish physiology, Academic Press, New York, pp 361-424

Bower NI, Li X, Taylor R, Johnston IA (2008) Switching to fast growth: the insulin-like growth factor (IGF) system in skeletal muscle of Atlantic salmon. J Exp Biol 211:3859-3870

Bower NI, Taylor RG, Johnston IA (2009) Phasing of muscle gene expression with fasting-induced recovery growth in Atlantic salmon. Front Zool 6:18

Brooks S, Johnston IA (1993) Influence of development and rearing temperature on the distribution, ultrastructure and myosin sub-unit composition of myotomal muscle-fibre types in the plaice Pleuronectes platessa. Mar Biol 117:501-513

Calvo J, Johnston IA (1992) Influence of rearing temperature on the distribution of muscle-fiber types in the turbot Scophthalmus maximus at metamorphosis. J Exp Mar Biol Ecol 161:45-55

Campinho MA, Silva N, Nowell MA, Llewellyn L, Sweeney GE, Power DM (2007) Troponin T isoform expression is modulated during Atlantic halibut metamorphosis. BMC Dev Biol 7:71

Campos C, Valente LM, Borges P, Bizuayehu T, Fernandes JM (2010) Dietary lipid levels have a remarkable impact on the expression of growth-related genes in Senegalese sole (Solea senegalensis Kaup). J Exp Biol 213:200-209

Campos C, Valente LMP, Conceição L, Engrola S, Sousa V, Rocha E, Fernandes JMO (2013) Incubation temperature induces changes in muscle cellularity and gene expression in Senegalese sole (Solea senegalensis). Gene 516:209-217

Cao Y, Kumar RM, Penn BH, Berkes CA, Kooperberg C, Boyer LA, Young RA, Tapscott SJ (2006) Global and gene-specific analyses show distinct roles for Myod and Myog at a common set of promoters. EMBO J 25:502-511

Capilla E, Teles-García A, Acerete L, Navarro I, Gutiérrez J (2011) Insulin and IGF-I effects on the proliferation of an osteoblast primary culture from sea bream (Sparus aurata). Gen Comp Endocrinol 172:107-114

Darias MJ, Zambonino-Infante JL, Hugot K, Cahu CL, Mazurais D (2008) Gene expression patterns during the larval development of European sea bass (Dicentrarchus labrax) by microarray analysis. Mar Biotechnol 10:416-428

de Hoon MJL, Imoto S, Nolan J, Miyano S (2004) Open source clustering software. Bioinformatics 20:1453-1454

Dedieu S, Mazères G, Cottin P, Brustis JJ (2002) Involvement of myogenic regulator factors during fusion in the cell line $\mathrm{C} 2 \mathrm{C} 12$. Int $\mathrm{J}$ Dev Biol 46:235-241

Fauconneau B, Andre S, Chmaitilly J, Le Bail PY, Krieg F, Kaushik SJ (1997) Control of skeletal muscle fibres and adipose cells size in the flesh of rainbow trout. J Fish Biol 50:296-314

Fernández I, Darias M, Andree KB, Mazurais D, Zambonino-Infante JL, Gisbert E (2011) Coordinated gene expression during gilthead sea bream skeletogenesis and its disruption by nutritional hypervitaminosis A. BMC Dev Biol 11:7 
Ferri P, Barbieri E, Burattini S, Guescini M, D’Emilio A, Biagiotti L, Del Grande P, De Luca A, Stocchi V, Falcieri E (2009) Expression and sub-localization of myogenic regulatory factors during the differentiation of skeletal muscle C2C12 myoblasts. J Cell Biochem 108: 1302-1317

Funkenstein B, Skopal T, Rapoport B, Rebhan Y, Du SJ, Radaelli D (2007) Characterization and functional analysis of the 5' flanking region of myosin light chain-2 gene expressed in white muscle of gilthead sea bream (Sparus aurata). Comp Biochem Physiol 2D: 187-199

Funkenstein B, Rebhan Y, Skopal T (2009) Molecular cloning and characterization of follistatin in the gilthead sea bream, Sparus aurata. Mol Biol Rep 36:501-511

Galloway TF, Kjorsvik E, Kryvi H (1999a) Muscle growth and development in Atlantic cod larvae (Gadus morhua L.), related to different somatic growth rates. J Exp Biol 202:2111-2120

Galloway TF, Kjorsvik E, Kryvi H (1999b) Muscle growth in yolk-sac larvae of the Atlantic halibut as influenced by temperature in the egg and yolk-sac stage. J Fish Biol 55:26-43

Gauthier GF, Lowey S, Benfield PA, Hobbs AW (1982) Distribution and properties of myosin isozymes in developing avian and mammalian skeletal muscle fibres. J Cell Biol 92:472-484

Georgiou S, Makridis P, Dimopoulos D, Power DM, Mamuris Z, Moutou KA (2014) Myosin light chain 2 isoforms in gilthead sea bream (Sparus aurata L.): molecular growth markers at early stages. Aquaculture 432:434-442

Gerlach GF, Turay L, Malik KT, Lida J, Scutt A, Goldspink G (1990) Mechanisms of temperature acclimation in the carp: a molecular biological approach. Am J Physiol 259:R237-R244

Gibson S, Johnston IA (1995) Temperature and development in larvae of the turbot Scophthalmus maximus. Mar Biol 124:17-25

Hevroy EM, Jordal AEO, Hordvik I, Espe M, Hemre GI, Olsvik PA (2006) Myosin heavy chain mRNA expression correlates higher with muscle protein accretion than growth in Atlantic salmon, Salmo salar. Aquaculture 252:453-461

Hirayama Y, Kobiyama A, Ochiai Y, Watabe S (1998) Two types of mRNA encoding regulatory light chain in carp fast skeletal muscle differ in their 3' non-coding regions and expression patterns following temperature acclimation. J Exp Biol 201:2815-2820

Ishibashi J, Perry RL, Asakura A, Rudnicki MA (2005) MyoD induces myogenic differentiation through cooperation of its NH2- and COOH-terminal regions. J Cell Biol 171:471-482

Johnston IA (1999) Muscle development and growth: potential implications for flesh quality in fish. Aquaculture 177:99-115

Johnston IA (2006) Environment and plasticity of myogenesis in teleost fish. J Exp Biol 209:2249-2264

Johnston IA, Vieira VLA, Abercrombie M (1995) Temperature and myogenesis in embryos of the Atlantic herring Clupea harengus. $\mathrm{J}$ Exp Biol 198:1389-1403

Johnston IA, Mclay HA, Abercromby M, Robins D (2000) Early thermal experience has different effects on growth and muscle fiber recruitment in spring- and autumn-running Atlantic salmon populations. J Exp Biol 203:2553-2564

Johnston IA, Manthri S, Alderson R, Campbell P, Mitchell D, Whyte D, Dingwall A, Nickell D, Selkirk C, Robertson B (2002) Effects of dietary protein level on muscle cellularity and flesh quality in Atlantic salmon with particular reference to gaping. Aquaculture 210:259-283

Johnston IA, Abercromby M, Vieira VL, Sigursteindóttir RJ, Kristjánsson BK, Sibthorpe D, Skúlason S (2004) Rapid evolution of muscle fiber number in post-glacial populations of Arctic charr Salvelinus alpinus. J Exp Biol 207:4343-4360

Kassar-Duchossoy L, Gayraud-Morel B, Gomès D, Rocancourt D, Buckingham M, Shinin V, Tajbakhsh S (2004) Mrf4 determines skeletal muscle identity in Myf5:Myod double-mutant mice. Nature 431:466-471
Kiessling A, Storebakken T, Asgard T, Kiessling KH (1991) Changes in the structure and function of the epaxial muscle of rainbow trout (Oncorhynchus mykis) in relation to ration and age. I. Growth dynamics. Aquaculture 93:335-356

Lee SJ, McPherron AC (2001) Regulation of myostatin activity and muscle growth. Proc Natl Acad Sci U S A 98:9306-9311

Maccatrozzo L, Bargelloni L, Radaelli G, Mascarello F, Patarnello T (2001a) Characterization of the myostatin gene in the gilthead seabream (Sparus aurata): sequence, genomic structure, and expression pattern. Mar Biotechnol 3:224-230

Maccatrozzo L, Bargelloni L, Cardazzo B, Rizzo G, Patarnello T (2001b) A novel second myostatin gene is present in teleost fish. FEBS Lett 509:36-40

Matzuk MM, Lu N, Vogel H, Sellheyer K, Roop DR, Bradley A (1995) Multiple defects and perinatal death in mice deficient in follistatin. Nature 374:360-363

Medeiros EF, Phelps MP, Fuentes FD, Bradley TM (2009) Overexpression of follistatin in trout stimulates increased muscling. Am J Physiol 297:R235-R242

Mingarro M, Vega-Rubín de Celis S, Astola A, Pendón C, Valdivia MM, Pérez-Sánchez J (2002) Endocrine mediators of seasonal growth in gilthead sea bream (Sparus aurata): the growth hormone and somatolactin paradigm. Gen Comp Endocrinol 128:102-111

Montserrat N, Sánchez-Gurmaches J, García de la Serrana D, Navarro MI, Gutiérrez J (2007) IGF-I binding and receptor signal transduction in primary cell culture of muscle cells of gilthead sea bream: changes throughout in vitro development. Cell Tissue Res 330:503-513

Montserrat N, Capilla E, Navarro I, Gutiérrez J (2012) Metabolic effects of insulin and IGFs on gilthead sea bream (Sparus aurata) muscle cells. Front Endocrinol 3:55

Moutou KA, Canario AV, Mamuris Z, Power DM (2001) Molecular cloning and sequence of Sparus aurata skeletal myosin light chains expressed in white muscle: developmental expression and thyroid regulation. J Exp Biol 204:3009-3018

Moutou KA, Silva N, Mamuris Z, Power DM (2005) Expression of myosin light chains 1 and 2 in the developing fast muscle of gilthead sea bream (Sparus aurata). Arch Tierz Dumm 48 (Special Issue):75

Moutou KA, Godina M, Georgiou S, Gutiérrez J, Mamuris Z (2009) Myosin light chain 2 in gilthead sea bream (Sparus aurata): a molecular marker of muscle development and growth. In: Sorgeloos $\mathrm{P}$, Olsen Y, Tandler A (eds) Book of Abstracts, 5th Fish and Shellfish Larviculture Symposium 7-10 September 2009. Laboratory of Aquaculture \& Artemia Reference Center, Ghent, pp 151-152

Nadjar-Boger E, Funkenstein B (2011) Myostatin-2 gene structure and polymorphism of the promoter and first intron in the marine fish Sparus aurata: evidence for DNA duplications and/or translocations. BMC Genet 12:22

Ostbye TK, Galloway TF, Nielsen C, Gabestad I, Bardal T, Andersen O (2001) The two myostatin genes of Atlantic salmon (Salmo salar) are expressed in a variety of tissues. Eur J Biochem 268:5249-5257

Overturf K, Hardy RW (2001) Myosin expression levels in trout muscle: a new method for monitoring specific growth rates for rainbow trout Oncorhynchus mykiss (Walbaum) on varied planes of nutrition. Aquac Res 32:315-322

Patruno M, Radaelli G, Mascarello F, Candia Carnevali MD (1998) Muscle growth in response to changing demands of functions in the teleost Sparus aurata (L.) during development from hatching to juvenile. Anat Embryol 198:487-504

Patruno M, Maccatrozzo L, Funkenstein B, Radaelli G (2006) Cloning and expression of insulin-like growth factor I and II in the shi drum (Umbrina cirrosa). Comp Biochem Physiol 144B:137-151

Patruno M, Sivieri S, Poltronieri C, Sacchetto R, Maccatrozzo L, Martinello T, Funkenstein B, Radaelli G (2008) Real-time polymerase chain reaction, in situ hybridization and immunohistochemical localization of insulin-like growth factor-I and myostatin during 
development of Dicentrarchus labrax (Pisces: Osteichthyes). Cell Tissue Res 331:643-658

Patterson SE, Mook LB, Devoto SH (2008) Growth in the larval zebrafish pectoral fin and trunk musculature. Dev Dyn 237:307-315

Perrot V, Moiseeva EB, Gozes Y, Chan SJ, Ingleton P, Funkenstein B (1999) Ontogeny of the insulin-like growth factor system (IGF-I, IGF-II, and IGF-1R) in gilthead seabream (Sparus aurata): expression and cellular localization. Gen Comp Endocrinol 116:445-460

Pfaffl MW (2001) A new mathematical model for relative quantification in real-time RT-PCR. Nucleic Acids Res 29:e45

Pitkänen TI, Xie SQ, Krasnov A, Mason PS, Mölsä H, Stickland NC (2001) Changes in tissue cellularity are associated with growth enhancement in genetically modified Arctic charr (Salvelinus alpinus L.) carrying recombinant growth hormone gene. Mar Biotechnol 3: $188-197$

Ramírez-Zarzosa G, Gil F, Latorre R, Ortega A, García-Alcaráz A, Abellán E, Vázquez JM, López-Albors $\mathrm{O}$, Arencibia A, Moreno $\mathrm{F}$ (1995) The larval development of lateral musculature in gilthead sea bream Sparus aurata and sea bass Dicentrarchus labrax. Cell Tissue Res 280:217-224

Rebhan Y, Funkenstein B (2008) Inhibition of fish myostatin activity by recombinant fish follistatin and myostatin prodomain: potential implications for enhancing muscle growth in farmed fish. Aquaculture 284:231-238

Rius-Francino M, Acerete L, Jiménez-Amilburu V, Capilla E, Navarro I, Gutiérrez J (2011) Differential effects on proliferation of GH and IGFs in sea bream (Sparus aurata) cultured myocytes. Gen Comp Endocrinol 172:44-49

Rowlerson A, Veggetti A (2001) Cellular mechanisms of post-embryonic muscle growth in aquaculture species. In: Johnston IA (ed) Muscle devevelopment and growth. Academic Press, San Diego, pp $103-140$

Rowlerson A, Mascarello F, Radaelli G, Veggetti A (1995) Differentiation and growth of muscle in the fish Sparus aurata (L). II. Hyperplastic and hypertrophic growth of lateral muscle from hatching to adult. J Muscle Res Cell Motil 16:223-236

Salze G, Alami-Durante H, Barbut S, Marcone M, Bureau DP (2014) Nutrient deposition partitioning and priorities between body compartments in two size classes of rainbow trout in response to feed restriction. Br J Nutr 111:1361-1372

Sánchez A, Robbins J (1994) Unprocessed myogenin transcripts accumulate during mouse embryogenesis. J Biol Chem 269:1587-1590

Sánchez-Ramos I, Cross I, MácHa J, Mártinez-Rodríguez G, Krylov V, Rebordinos L (2012) Assessment of tools for marker-assisted selection in a marine commercial species: significant association between MSTN-1 gene polymorphism and growth traits. ScientificWorldJournal 2012:369802
Sarropoulou E, Power DMP, Mamuris Z, Moutou KA (2006) The two isoforms of myosin light chain 2 in gilthead sea bream (Sparus aurata); alternative polyadenylation site selection and tissue expression. Arch Tierz Dumm 49 (Special Issue):92-96

Seiliez I, Sabin N, Gabillard JC (2012) Myostatin inhibits proliferation but not differentiation of trout myoblasts. Mol Cell Endocrinol 351: 220-226

Silva P, Valente LM, Galante MH, Andrade CA, Monteiro RA, Rocha E (2009) Dietary protein content influences both growth and size distribution of anterior and posterior muscle fibres in juveniles of Pagellus bogaraveo (Brunnich). J Muscle Res Cell Motil 30:29-39

Stoiber W, Sanger AM (1996) An electron microscopic investigation into the possible source of new muscle fibres in teleost fish. Anat Embryol 194:569-579

Tiago DM, Laizé V, Cancela ML (2008) Alternatively spliced transcripts of Sparus aurata insulin-like growth factor 1 are differentially expressed in adult tissues and during early development. Gen Comp Endocrinol 157:107-115

Valente LMP, Rocha E, Gomes EFS, Silva MW, Oliveira MH, Monteiro RAF, Fauconneau B (1999) Growth dynamics of white and red muscle fibres in fast- and slow-growing strains of rainbow trout. J Fish Biol 55:675-691

Vandesompele J, De Preter K, Pattyn F, Poppe B, Van Roy N, De Paepe A, Speleman F (2002) Accurate normalization of real-time quantitative RT-PCR data by geometric averaging of multiple internal control genes. Genome Biol 3:research0034

Veggetti A, Mascarello F, Scapolo P, Rowlerson A (1990) Hyperplastic and hypertrophic growth of lateral muscle in Dicentrarchus labrax (L.). Anat Embryol 182:1-10

Veggetti A, Rowlerson A, Radaelli G, Arrighi S, Domeneghini C (1999) Post-hatching development of the gut and lateral muscle in the sole. J Fish Biol 55:44-65

Weatherley AH, Gill HS, Rogers SC (1979) Growth dynamics of muscle fibres, dry weight, and condition in relation to somatic growth rate in yearling rainbow trout (Salmo gairdneri). Can J Zool 57:2385-2392

Weatherley AH, Gill HS, Lobo AF (1988) Recruitment and maximal diameter of axial muscle fibres in teleosts and their relationship to somatic growth and ultimate size. J Fish Biol 33:851-859

Whalen RG, Sell SM, Butler-Browne GS, Schwartz K, Bouveret P, Pinset-Härström I (1981) Three myosin heavy chain isozymes appear sequentially in rat muscle development. Nature 292:805-809

Zar JH (1996) Biostatistical analysis, 3rd edn. Prentice-Hall, New Jersey

Zhang W, Behringer RR, Olson EN (1995) Inactivation of the myogenic bHLH gene MRF4 results in up-regulation of myogenin and rib anomalies. Genes Dev 9:1388-1399 